\title{
Gestational Monosodium Glutamate Exposure Effects on Anogenital Distance of Male Rat Pups
}

\author{
Amelya Permata Sari, ${ }^{1}$ Cimi Ilmiawati, ${ }^{2}$ Mohamad Reza ${ }^{3}$ \\ ${ }^{1}$ Postgraduate Program in Midwifery, Faculty of Medicine, Andalas University, Padang, Indonesia, \\ ${ }^{2}$ Division of Environmental Toxicology, Department of Pharmacology, Faculty of Medicine Universitas Andalas, \\ Padang, Indonesia, ${ }^{3}$ Department of Biology, Faculty of Medicine Universitas Andalas, Padang, Indonesia
}

\begin{abstract}
High-dose Monosodium Glutamate (MSG) expo sure increases the estrogen level in pregnant rats. However, there are limited data available on whether the MSG-related maternal hormonal effects can affect male litters' genitalia phenotype. This study aimed to analyze the impact of MSG on estrogen level in pregnant rats and anogenital distance in male pups. Experiment for this study was performed at the animal facility of Biomedical Laboratory at the Faculty of Medicine, Universitas Andalas, from April 2019 to February 2020. Pregnant Wistar rats were given MSG orally at 2 and $4 \mathrm{mg} / \mathrm{g}$ body weight (BW) for 20 days. On day 21, pregnant rats were sacrificed and blood was drawn intracardially. Estradiol serum level was measured by ELISA. Male pups were counted, and the anogenital distance (AGD) was measured. Maternal serum estradiol levels were statistically analyzed by One-Way ANOVA and the AGD of male litters were analyzed by the Kruskal-Wallis test. Results showed that perinatal MSG exposure increased the estradiol level $(26.3 \pm 4.5 \mathrm{pg} / \mathrm{mL} ; 37.5 \pm 6.7 \mathrm{pg} / \mathrm{mL} ; 62.1 \pm 8.2 \mathrm{pg} / \mathrm{mL}$ in control, $2 \mathrm{mg} / \mathrm{gBW}$, and $4 \mathrm{mg} /$ gBW group, respectively [mean \pm SD; $p=<0.001])$ and decreased the AGD ( $4 \mathrm{~mm} ; 3 \mathrm{~mm} ; 1.5 \mathrm{~mm}$ in control, $2 \mathrm{mg} /$ $\mathrm{gBW}$, and $4 \mathrm{mg} / \mathrm{gBW}$ group, respectively [median; $\mathrm{p}=<0.01$ ]) in a dose-dependent manner. Thus, MSG exposure during pregnancy is a risk factor for male rat feminization.
\end{abstract}

Keywords: Anogenital distance, estrogen, gestation, male, monosodium glutamate

\section{Efek Paparan Monosodium Glutamat Pada Masa Gestasi Terhadap Jarak Anogenital Bayi Tikus Jantan}

\begin{abstract}
Abstrak
Paparan monosodium glutamat (MSG) pada dosis tinggi diketahui meningkatkan kadar estrogen pada tikus bunting. Namun masih sedikit data mengenai pengaruh efek hormonal MSG pada induk terhadap fenotip genitalia bayi jantan. Penelitian ini bertujuan menganalisis pengaruh MSG terhadap kadar estrogen tikus bunting dan jarak anogenital bayi jantan. Penelitian ini dilakukan di fasilitas hewan Laboratorium Biomedik Fakultas Kedokteran Universitas Andalas dari April 2019 sampai Februari 2020. Tikus Wistar bunting diberi MSG secara oral pada dosis 2 and $4 \mathrm{mg} / \mathrm{gBB}$ selama 20 hari. Pada hari ke-21, tikus bunting dikorbankan dan darahnya diambil intrakardial. Kadar estradiol serum diukur menggunakan ELISA. Bayi jantan dihitung dan jarak anogenital (JAG) diukur. Kadar estradiol serum induk dan JAG bayi dianalisis secara statistik. Hasil penelitian menunjukkan bahwa paparan MSG pada masa gestasi meningkatkan kadar estradiol level $(26.3 \pm 4.5 \mathrm{pg} / \mathrm{mL} ; 37.5 \pm 6.7 \mathrm{pg} / \mathrm{mL}$; $62.1 \pm 8.2 \mathrm{pg} / \mathrm{mL}$ pada kelompok kontrol, $2 \mathrm{mg} / \mathrm{gBB}$, dan $4 \mathrm{mg} / \mathrm{gBB}$, berturut-turut [rerata $\pm \mathrm{SD} ; \mathrm{p}=<0.001 ;$ OneWay ANOVA]) dan menurunkan JAG ( $4 \mathrm{~mm} ; 3 \mathrm{~mm} ; 1.5 \mathrm{~mm}$ pada kelompok kontrol, $2 \mathrm{mg} / \mathrm{gBB}$, dan $4 \mathrm{mg} / \mathrm{gBB}$, berturut-turut [median; $\mathrm{p}=<0.01$; Kruskal-Wallis]) sesuai peningkatan dosis. Simpulan, paparan MSG selama kehamilan merupakan faktor risiko feminisasi pada anak tikus jantan.
\end{abstract}

Kata kunci: Estrogen, gestasi, jantan, jarak anogenital, monosodium glutamat

Corresponding Author: Mohamad Reza, Department of Biology Faculty of Medicine, Universitas Andalas Kampus Limau Manis, Pauh, PO BOX 49, Padang, West Sumatra, 25166, Indonesia, Email: reza@med.unand.ac.id 


\section{Introduction}

Monosodium glutamate (MSG) is a form of glutamic acid salt widely consumed worldwide. Glutamic acid can be found in food products containing high protein, such as meat, fish, cheese, and vegetables. The average estimated daily MSG consumption per person is $0.65 \mathrm{~g}$ in Indonesia, $1.90 \mathrm{~g}$ in Japan, $1.00 \mathrm{~g}$ in the US, and 0.57 g in Canada. ${ }^{1}$

MSG at a dose of $0.2 \mathrm{~g} / \mathrm{kg}$ body weight (BW) given for 14 days has been shown to induce severe ovarian damage in rats, while an MSG exposure of 3 and $6 \mathrm{~g} / \mathrm{kgBW}$ for 30 days has been shown to disrupt testicular morphology, affecting the testosterone level and sperm count, potentially causing partial infertility in men. ${ }^{2,3}$

A study on male rabbits revealed that MSG given at a dose of $1 \mathrm{~g} / \mathrm{kgBW}$ for 56 days suppresses luteinizing hormone (LH) and decreases the testosterone level without any pathological testicular lesion. ${ }^{4}$ MSG impairs ovarian function by inducing the secretion of LH and folliclestimulating hormone (FSH) from the anterior pituitary and estradiol from ovarian follicles by acting as a neurotransmitter. ${ }^{5}$ Monosodium glutamate exposure at $0.08 \mathrm{mg} / \mathrm{kgBW}$ for 14 days on female rats can cause degenerative and atrophic changes in the fallopian tubes. ${ }^{6}$

Increased estrogen or estrogen-like compound exposure affects male reproductive phenotype, which manifests as, among others, shorter anogenital distance (AGD), hypospadias, ${ }^{7}$ and feminization of seminal vesicle. ${ }^{8}$ MSG exposure has been shown to induce estrogen levels in adult female rats. ${ }^{9}$ The MSG effect on female reproductive organs through the interaction with the endocrine system by increasing the estradiol level may impact the hormone-sensitive development of male offsprings' genitalia. However, there are limited data available on whether gestational MSG exposure can decrease male AGD, a feminization marker.

This study aimed to investigate the effect of gestational exposure of MSG on maternal serum estrogen level and AGD of male offsprings.

\section{Methods}

The institutional research ethics committee of the Faculty of Medicine, Universitas Andalas has approved this study through the issuance of the Ethical Clearance No.581/KEP/FK/2019. The animal experimentation was conducted at the animal house facility of the Faculty Medicine Universitas Andalas from December 2019 to January 2020. Adult Wistar rats (8-10 week-old) weighing 170-190 grams were kept in cages at a temperature of $20^{\circ}-25^{\circ} \mathrm{C}$ and a $12 / 12$ hour light/dark cycle. Rats were fed standard chow (All feed- $3^{\circledR}$, PT. Central Proteina Prima Tbk, Medan) ad libitum.

Male and female rats were mated; pregnancy was confirmed by checking vaginal plugs (gestational day 1). Pregnant rats were randomly divided into three groups ( $\mathrm{n}=6 \mathrm{each}$ ). The control group was fed standard chow and water while the treatment group was given standard chow and given MSG orally at 2 and $4 \mathrm{mg} / \mathrm{gBW}$ at 10 AM daily using oral gavage for 20 days. ${ }^{10}$ On day 21, animals were anesthetized using Ketamine $0.15 \mathrm{~mL} / 200 \mathrm{gBW}$ and Xylazil $0.25 \mathrm{~mL} / 200 \mathrm{~g}$ BW intra-peritoneally. Then, $2 \mathrm{ml}$ of blood was drawn from the heart using a vacutainer. Blood samples were then centrifuged at 3,000 rpm for 15 minutes to separate the serum. Sera were stored in a freezer at $-20^{\circ} \mathrm{C}$ until analysis for estradiol by the ELISA method. All experiments were performed in duplicate.

Following blood drawing from the dams, all litters were surgically removed from the womb and were placed in 10\% neutral buffered formalin. Their genitalia were identified and male litters were separated then placed in a supine position, and AGD was measured as the distance between the anal rim and the genital papilla using a caliper and millimeter paper. Data on serum estradiol and AGD were examined for their normality before the analysis was performed. Data on serum estradiol was proven to have a normal distribution while the AGD data were non-normallydistributed. Based on this, comparison of serum estradiol level and AGD between groups were analyzed using One-Way ANOVA (followed by Bonferroni post hoc test) and Kruskal-Wallis (followed by Mann-Whitney $\mathrm{U}$ test), respectively. Results were considered to be statistically significant when p-value $<0.05$. All analyses were performed using IBM SPSS Statistics for Windows ver.25 (IBM Corporation, Armonk, NY).

\section{Results}

Bodyweight changes were measured periodically to monitor animal well-being during the experiment until the end of the study, and the result is presented in Figure 1. Body weight was shown to increase in all groups during 


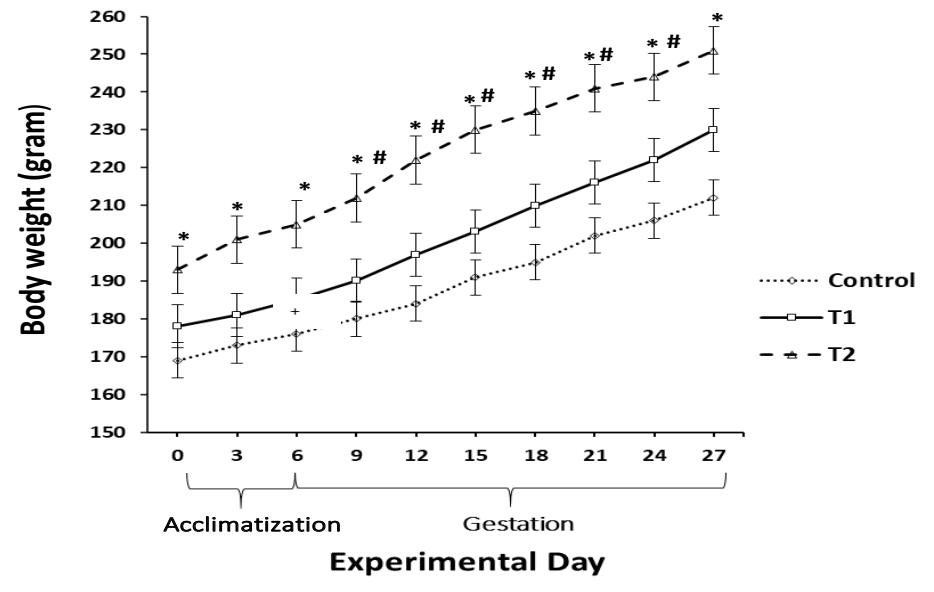

\section{Figure 1 Bodyweight Changes (gram) of Female Rats During the Acclimatization and} Gestational Period

Intergroup comparison for each point in time was analyzed by One-Way ANOVA followed by Bonferroni test. Results are presented in mean $\pm \mathrm{SD}$. *difference from control at $\mathrm{p}<0.05$; ${ }^{*}$ difference from $\mathrm{T}_{1}$ at $\mathrm{p}<0.05$.

the experiment with a statistically significant increase in the group receiving MSG at $4 \mathrm{mg} /$ $\mathrm{gBW} /$ day when compared to the group receiving $2 \mathrm{mg} / \mathrm{gBW} /$ day.

This study orally exposed female rats to two doses of MSG during the gestational period to validate the previous finding that MSG induces estradiol serum levels. ${ }^{9}$ This study corroborated the previous study and the result is presented in Figure 2. This study found a statistically significant elevation in serum estradiol level in pregnant rats orally exposed to MSG compared to the control group.

This study also measured male litter's AGD at birth to elucidate whether maternal gestational exposure to MSG affects male offspring's reproductive phenotype. The result is presented in Figure 3, showing a statistically significant

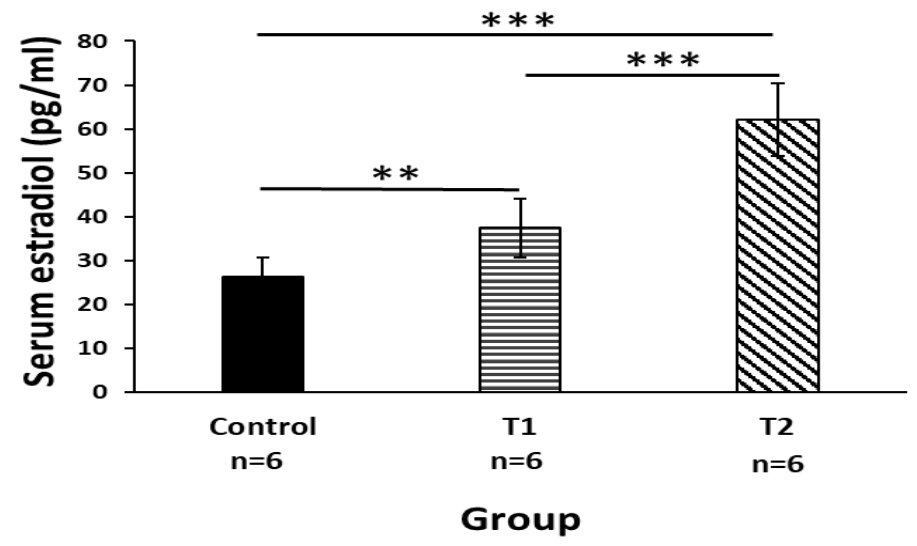

Figure 2 Serum Estradiol Level of Female Rats Exposed to MSG During Pregnancy (20 days)

Control group was given standard chow. Treatment groups were given standard chow and MSG orally at $2 \mathrm{mg} / \mathrm{g} \mathrm{BW} /$ day $\left(\mathrm{T}_{1}\right)$ and $4 \mathrm{mg} / \mathrm{g} \mathrm{BW} /$ day $\left(\mathrm{T}_{2}\right)$. Intergroup comparison was analyzed by One-Way ANOVA followed by Bonferroni test, presented as mean $\pm \mathrm{SD} .{ }^{* *} \mathrm{p}<0.01 ;{ }^{* * *} \mathrm{p}<0.001$. 


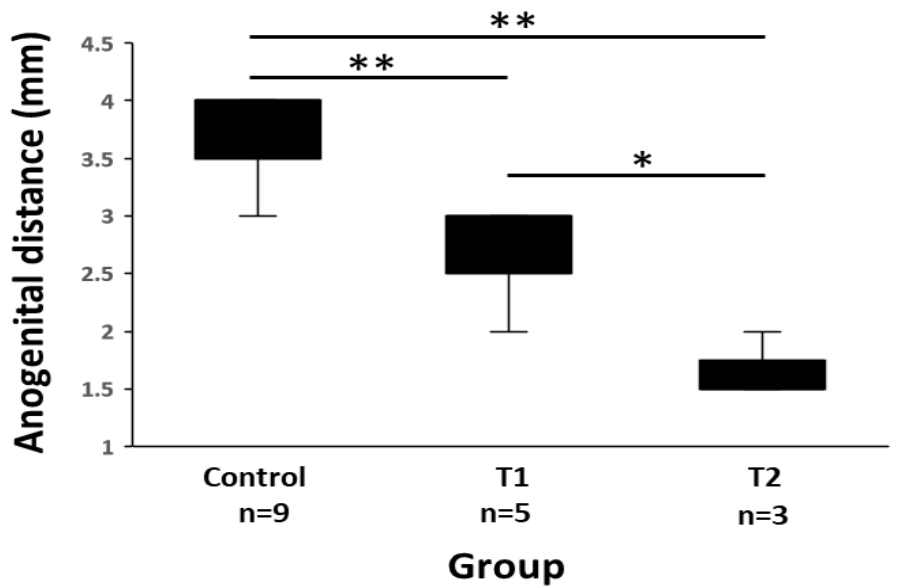

Figure 3 Anogenital Distance (AGD) of Male Pups Born from Dams Exposed to MSG During Pregnancy. AGD (mm) was measured at birth. Control group was given standard chow. Treatment groups were given standard chow and MSG orally at $2 \mathrm{mg} / \mathrm{gBW} /$ day $\left(\mathrm{T}_{1}\right)$ and $4 \mathrm{mg} / \mathrm{gBW} /$ day $\left(\mathrm{T}_{2}\right)$. Intergroup comparison was analyzed by Kruskal-Wallis followed by Mann-Whitney U test and presented as boxplot (the box is formed by interquartile range and the whiskers showed minimum and maximum value); ${ }^{*} \mathrm{p}<0.05 ;{ }^{* *} \mathrm{p}<0.01$

shortening of male AGD in the group consisting of dams exposed to $2 \mathrm{mg} / \mathrm{gBW} /$ day (median $3.0 \mathrm{~mm}$, interquartile range [IQR] $1.0 \mathrm{~mm}$ ) and $4 \mathrm{mg} / \mathrm{gBW} /$ day (median $1.5 \mathrm{~mm}$, IQR $0.25 \mathrm{~mm}$ ) when compared to the control group (median $4.0 \mathrm{~mm}$, IQR $0.5 \mathrm{~mm}$ ). Representative pictures of measurement for each group are shown in Figure 4.

To understand the effect of maternal gestational MSG exposure on maternal fertility, of the total number of pups from each dam was counted and the result is presented on Figure 5. Compared to the control group, gestational exposure to MSG resulted in lesser number of pups in both exposed groups, but only statistically significant in group exposed to MSG at $4 \mathrm{mg}$ / gBW/day ( $<<0.01$; Mann-Whitney U test).

\section{Discussion}

This study indicates that treatment groups exposed to MSG during the gestational period had a higher body weight than the control group, particularly with the exposure to higher dose of MSG (Figure 1). MSG can cause lesions in the hypothalamus; thus interfering with hypothalamic signals and leptin resistance. ${ }^{11}$ The exact mechanism for the effect of MSG on obesity is unknown. One plausible explanation is that MSG may trigger leptin resistance. Leptin is a hormone produced by fat cells in the body. In normal people, leptin will increase during meals in the blood and serves as a signal for the brain to stop eating. However, in people with leptin resistance, the brain does not respond to leptin
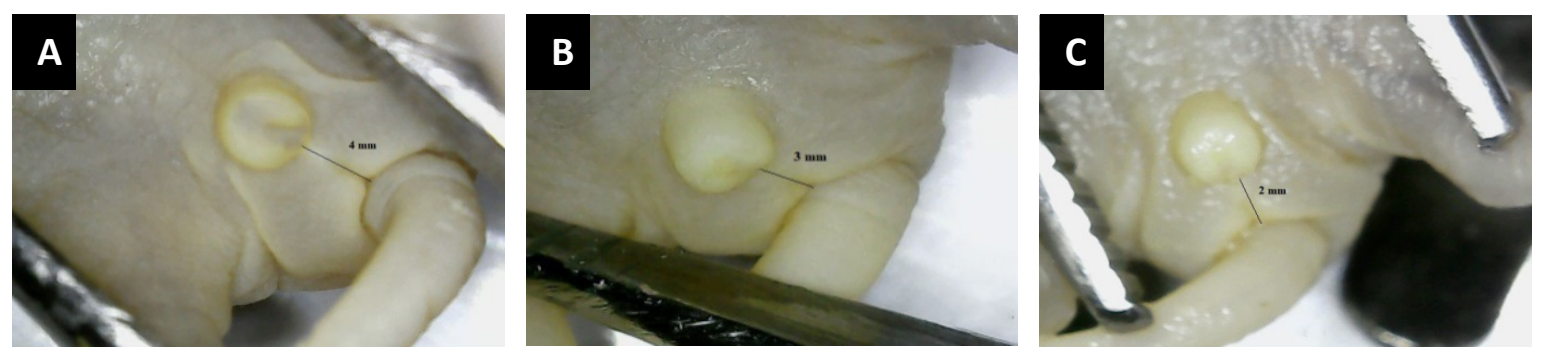

Figure 4 The Anogenital Distance at Birth (mm) in Male Pups Born from Dams Exposed to MSG During Pregnancy

A. Control. B. Born from dam exposed to MSG 2 mg/gBW/day for 20 days. C. Born from dam exposed to MSG $4 \mathrm{mg} / \mathrm{gBW} /$ day for 20 days. Picture is representative of each group 


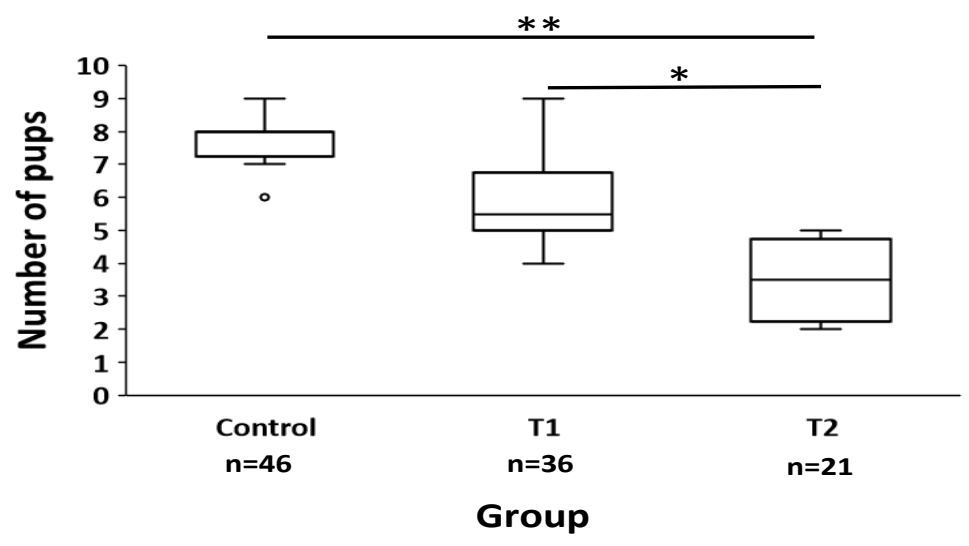

Figure 5 Total Number of Pups from Dams Exposed to MSG During Pregnancy. Control Group was Given Standard Chow

Treatment groups were given standard chow and MSG orally at $2 \mathrm{mg} / \mathrm{gBW} /$ day $\left(\mathrm{T}_{1}\right)$ and $4 \mathrm{mg} / \mathrm{gBW}$ day $\left(\mathrm{T}_{2}\right)$. Intergroup comparison was analyzed by Kruskal-Wallis followed by Mann-Whitney U test and presented as boxplot (the box is formed by interquartile range and the whiskers showed minimum and maximum value). $* \mathrm{p}<0.05 ;{ }^{* *} \mathrm{p}<0.01$

signals and satiety is not reached, leading to more food consumption. ${ }^{11}$

L-glutamate receptors may also influence the effect of MSG on body weight in the gastrointestinal tract connected to afferent fibers from the vagal nerve. ${ }^{12}$ The finding of this study is in line with previous research in rats given MSG, where an increase in body weight was observed, possibly due to the impairment of the hypothalamus and arcuate nucleus, resulting in a lack of control in energy absorption and expenditure. ${ }^{13}$ The increase in body weight may also occur because MSG stimulates the pancreas, causing hyperinsulinemia, leading to increased sugar conversion to glycogen and subsequent deposition in adipose tissue. ${ }^{14}$ Monosodium glutamate given at $4 \mathrm{mg} / \mathrm{gBW} /$ day during gestation in this study influenced the number of pups conceived by the dams. It is possible that gestational MSG exposure induces maternal obesity and metabolic syndrome, affecting the ovarian functions. MSG-exposed animals may suffer from irregular cycle and less ovulated oocyte ${ }^{15}$ hence lesser number of pups.

Monosodium glutamate impairs ovarian function by increasing LH and FSH's secretion from the anterior pituitary and estradiol from ovarian follicles through action as a neurotransmitter. Monosodium glutamate may stimulate glutamatergic neurons in the hypothalamus. In return, these neurons induce the synthesis and release of the gonadotropinreleasing hormone ( $\mathrm{GnRH}$ ), followed by increased
LH and FSH secretion from the anterior pituitary through a positive feedback mechanism. ${ }^{5}$ The result of this study is similar to a previous study in rats given oral MSG at 1, 2, and $4 \mathrm{mg} / \mathrm{gBW}$ for 21 days, where an increase in serum estrogen was observed in a dose-dependent manner. ${ }^{16}$

A previous study on male rats given diethylstilbestrol has shown a decrease in the testosterone level and the seminal vesicle' weight, leading to a significant reduction in AGD. ${ }^{17}$ The anogenital distance is a useful biological marker for detecting androgen deficiency in fetus and detecting disruptive endocrine effects. ${ }^{18}$ In humans, this will increasingly serve as a prospective biomarker, where shorter than average AGD in males reflects the probability of complications or reproductive problems in adulthood. ${ }^{19}$

In conclusion, gestational MSG exposure affects maternal serum estradiol and male pups' anogenital distance in rats.

\section{References}

1. Kurtanty D, Faqih DM, Upa NP. Review monosodium glutamate. Jakarta: Ikatan Dokter Indonesia; 2018

2. Oladipo IC, Adebayo EA, Kuye OM. Effect of monosodium glutamate in ovaries of female Sprague Dawley rats. Int J Microbiol Appl Sci. 2015;4(5):737-45.

3. Iamsaard S, Sukhorum W, Samrid R, Yimde 
J, Kanla P, Hipkaeo W, et al. The sensitivity of male reproductive organ to monosodium glutamate. Medica Academica. 2014;43(1): 3-9.

4. Okoye CN, Ochiogu LS, Onah CE. The effect of monosodium glutamate administration of the reproduction and serum biochemistry of adult male rabbits. Veterinary Medicine. 2016;61(3):141-47.

5. Mondal M, Sarkar K, Nath PN, Paul G. Monosodium glutamate suppresses the female reproductive function by impairing the function of ovary and uterus in the rat. Environ Toxicol. 2018;33(2):198-208.

6. Eweka AO, Eweka A, Om'iniabohs FAE. Histological studies of the effect of monosodium glutamate of the fallopian tubes of adult female Wistar rats. N Am J Med Sci. 2010;2(3):146-9.

7. Hsieh MH, Breyer BN, Eisenberg, ML, Baskin LS. Associations among hypospadias cryptorchidism, anogenital distance, and endocrine disruption. Curr Urol Rep. 2008; 9(2):137-42.

8. Walker VR, Jefferson WN, Couse JF, Korach KS. Estrogen receptor- $\alpha$ mediates diethylstilbestrol-induced feminization of the seminal vesicle male mice. Environ Health Perspect. 2012;120(4):560-5.

9. Zia MS, Qamar K, Hanif R, Khalil M. Effect of monosodium glutamate on the serum estrogen and progesterone levels in female rat and prevention of this effect with diltiazem. J Ayub Medical College Abbottabad. 2014;26(1):18-20.

10. Nwajei JC, Onuoha SC, Essien EB. Effect of oral administration of selected food seasonings consumed in Nigeria on some sex hormones of Wistar albino rats. Journal Biotechnology Biochemistry. 2015;1(5):15-21.

11. He K, Du S, Xun P, Sharma S, Wang H, Zhai $F$ et al. Consumption of monosodium glutamate in relation to incidence of overweight in Chinese adult: China health and nutrition survey (CHNS). Am J Clin Nutr. 2011;93(6):1328-36.

12. Onaolapo OJ, Onaolapo AY, Akanmu MA, Gbola O. Evidence of alterations in brain structure and antioxidant status following low dose monosodium glutamate ingestion. Pathophysiology. 2016;23:147-56.

13. Afifi MM, Abbas AM. Monosodium glutamate versus diet-induced obesity in pregnant rats and their offspring. Acta Physiologica Hungarica. 2011;98(2):177-88.

14. Ogbuagu EO, Airadion AI, Okoroukwu VN, Ogbuagu U, Ekonjoku JA. Effect of Monosodium glutamate on body weight and alanine aminotransferase activity in wistar rats. International Research Journal of Gastroenterology and Hepatology. 2019;2(2):1-8.

15. Gaspar RS, Benevides ROA, Fontelles JLL, Vale CC, França LM, Barros PTS et al. Reproductive alterations in hyperinsulinemic but normoandrogenic MSG obese female rats. J Endocrinol. 2016;229(2):61-72.

16. Obochi GO, Malu SP, Abang MO, Alozie Y, Iyam MA. Effect of garlic on monosodium glutamate induced fibroid in wistar rats. Pak J Nutr. 2009;8(7): 970-6.

17. Mitchell RT, Mungall W, McKinnell C, Sharpe RM, Cruickshanks L, Milne L, et al. Anogenital distance plasticity in adulthood: Implication for its use as a biomarker of fetal androgen action. Endocrinology. 2015;156(1):24-31.

18. Thankamony A, Lek N, Carroll D, Williams M, Dunger DB, Acerini CL, et al. Anogenital distance and penile length in infants with hypospadias or cryptorchidism: comparison with normative data. Environ Health Perspect. 2014; 122(2):207-11.

19. Gallavan RH, Holson JF, Stump DG, Knapp JF, Reynolds VL. Interpreting the toxicologic significance of alterations in anogenital distance: potential for confounding effect of progeny body weights. Reprod Toxicol. 1999;13(5):383-90. 